\title{
Park of the Affects: Communication, to Be Together and Recognition in the Intersubjectives Relations of Young People in Their Experience of Inhabit a Park
}

\author{
Mónica Marión Cataño Otálora \\ Department of Language and Communication, Pontificia Universidad Javeriana, Cali, Colombia \\ Email:mmarion@javerianacali.edu.co
}

How to cite this paper: Otálora, M. M. C. (2017). Park of the Affects: Communication, to Be Together and Recognition in the Intersubjectives Relations of Young People in Their Experience of Inhabit a Park. Advances in Journalism and Communication, 5, 71-82.

https://doi.org/10.4236/ajc.2017.52004

Received: March 6, 2017

Accepted: June 10, 2017

Published: June 15, 2017

Copyright $\odot 2017$ by author and Scientific Research Publishing Inc. This work is licensed under the Creative Commons Attribution International License (CC BY 4.0).

http://creativecommons.org/licenses/by/4.0/

\section{(c) (i) Open Access}

\begin{abstract}
This article presents a research done with young people in the city of CaliColombia and investigates their ways of being together, their forms of recognition and their intersubjectives relationships that underlie the experience of inhabiting a certain park. The affective turn of cultural studies and Spinoza's affective theory are those that illuminate the work that corresponds to a comprehensive study with an ethnographic approach and takes up the narratives of young people to describe the topophilia or room experience. The main results of the research point to the affective communities as the new forms of grouping of young people, the language of affection, the mixing of expressive languages with those that weave their communicative ties and perform their practices of resistance in defense of place, which is not only a place to be but is constituted instead of being.
\end{abstract}

Keywords

Language of Affection, Topophilia, Artivism, Recognition

\section{Introduction}

The young ${ }^{1}$ population of Colombia in 2014 was estimated at 12,644,492 (DANE, 2014), corresponding to the $26.52 \%$ of Colombians, of which $1,179,227$ reside in the department of Valle del Cauca. The $38 \%{ }^{2}$ of the total population of

\footnotetext{
${ }^{1}$ There is no consensus in the institutions to define the age range of young people, for the United Nations youth corresponds to a period of time lived between the ages of 15 and 24, while the Colombian Youth Citizenship Statute defines the rank among 14 and 28 years old.

${ }^{2}$ The percentage is estimated from the total population of the department to 2014: 4,566,593 taken from the municipal planning document Cali in figures and dividing by the information taken from the Youth Observatory to 2014: 1,179,227. Both sources draw from the statistics provided by the National Administrative Department of Statistics-DANE.
} 
the department is young.

In what concerns to Cali, the capital of the department, there is no data on the number of young people living in the city; however, the existing information, related to schooling and violence, places young people as a vulnerable population as they constitute themselves as the main victims and perpetrators of violence. According to the Cali documentation (Alcaldía de Santiago de Cali, 2013) it figures that in 2012, 1609 cases of family violence were reported between 15 - 29 year olds, of which 1549 represented forms of psychological, physical, and neglect of women. In this same age group, there were 162 cases of sexual abuse in women, 5 in men and 21 cases of suicide in men and 2 in women.

The data are less encouraging when reviewing the social observatory figures; the main cause of mortality in the city is murders, which were up to 1844 cases in 2012 and in 2013, they were up to 1959, according to the Social Observatory (Alcaldía de Santiago de Cali, 2012) the $30 \%$ of the victims of murder were people aged between 18 and 25. Although the situation is complex, the problem is accentuated when the media in their information programs only allude to young people when they are the actors and perpetrators of the social situation of the city, even though these are not the only representations and performances of the young people from Cali.

In the La Loma de la Cruz handicraft park, groups of boys and youth cultures stay from Thursday to Saturday. This park is a public place located between two popular neighborhoods of the city in which their inhabitants, artisans, merchants and young people have complex interactions traversed by the tension of groups that are located in the park with different interests.

The presence of the young people, their ways of being together led to the research that was proposed as a general objective to understand the experience of inhabiting the Loma de la Cruz Handicraft Park in the city of Cali-Colombia, Latin America, from the intersubjective relationships of young people and as specific objectives: 1) Describe the processes of Communication from the interactions and languages with which the various young people communicate in the experience of inhabiting the park, 2) analyze the ways of being together with young people by identifying the relationships and tensions that underlie their experience; Ways of recognition-and contempt-that arise from the co-presence relationships between the young people living in the place and the other people who make use of the park.

The importance of research in the social field lies in understanding the actions of young people to demonstrate their desire for recognition and social and political visibility in a society that marginalizes and excludes them. Likewise, the importance in the academic field is to resume the role of the emotions and feelings present in the youth interactions as a way of constructing their subjectivities to make a reading from the field of communication and culture that historically has focused in media studies and recently in TIC.

\section{Theoretical Bases}

The research is based on three axes: 1) From cultural studies in which commu- 
nication is studied and political processes are given the consumption processes in which popular culture provides raw material to experiment and extrapolate social identities in postmodern societies, so reflected by rock music, which is perceived as a laboratory for the production of identities of young persons seeking an independent self (Curran, Morley, \& Walkerdine, 1998). According to Sarto (2012), in 1990 he took up the so-called affective turn of Cultural Studies, which was produced in 1990 from various transdisciplinary research fields such as women's studies, queer studies and institutionalized cultural studies, and coincides with Lara \& Domínguez (2013) in pointing out the texts Autonomy of affect by Massumi published in 1995 and Shem in the cybernetic fold of Sedgwick and Frank as pioneers in evidencing the affective turn, which later is formalized with the book The Affective Turn of Ticineto and Halley, published in 2007.

For the understanding of the affections, the Theory of Affects is taken up, of which Spinoza occupied itself in the seventeenth century when he wrote the Ethics demonstrated according to the geometric order (Spinoza, 1980) and in his text heaffirms that affections are affections of the body by which the power of action of the body increases, diminishes or is favored or impaired; therefore, affection is an action or a passion and actions are directly related to ideas that may be adequate or inadequate. For Spinoza there are two affections concerning the soul and the body, the affection of joy and the affection of sadness. The first derives in pleasure and rejoicing and the second in pain and melancholy, these affects depend on the act or suffering of the human being.

The second is the understanding of affective communication in the intersubjective relationships of young people and the "link" they establish with the place, which in turn is significant in that they do not occupy the park, inhabit the place and dwellhere, as a theory of the place in architecture, is linked to the spatial dimension that is shared with others and links them as spacers, charged with meaning and meaning. The relation between being and being in dwelling occurs as a place of being (Yory, 2007).

The third axis of construction of the referents from which he makes the approach to the communicative and intersubjective phenomenon among young people is the one that Honneth (2010) brings in his theory of recognition. Honneth's point of departure for presenting a conception of social morality from recognition is the moral damage that is experienced as injustice. Physical harm constitutes a moral injustice if the affected person sees in him an act that intentionally belittles him in an essential aspect of his well-being (Honneth, 2010). It identifies three forms of disparagement that underlie three forms of recognition. The first form of contempt is torture or rape; the second, deprivation of rights and social exclusion, and the third, social degradation. The forms of recognition of each form of contempt are love, legal recognition and solidarity, respectively.

\section{Methodology}

The study corresponds to a qualitative research of ethnographic cut in which participant observation was carried out, social cartography and collected narra- 
tives of 13 young people attached to different youth cultures. Likewise, the social interview with semi structured questionnaire was used as an instrument for collecting the information of adults, neighbors of the park and artisans.

This duty was done in four phases, with time dedicated to the collection/ processing of the information and to live the experience, phases in which the bond was strengthened with the different actors, participants of the process.

In the first phase or exploratory inquiry, we turn to the "phenomenology of the experiences of thinking and knowing" (Moran, 2011) to present the project, its objectives and analytical categories.

The second phase of the qualitative methodology consisted in performing the urban ethnography, initially non-participant to observe the permanence of the youth cultures their permanence in the park.

It was necessary to carry out strategies of approach to interact with the young people in the third phase: The creation of the Fan Page entitled Park of Affects, a virtual scenario that led to the rapprochement, exploration of the worlds of life of young people through their Facebook once they stablished a "friendship" and shared photography, which allowed to record events, to stop moments and to portray the faces and bodies of the young people and later to share them in the Fan page.

In this phase interviews were made to 6 artisans and 5 neighbors and the narratives of 13 young people were collected through conversations recorded in audio.

In the last phase of the work, information was organized, systematized through narrative matrices and data operation tables to elaborate the results, findings and conclusions.

\section{Results}

\subsection{Result 1: To Inhabit the Place}

For young people, their living in the park is related to freedom, with the comfort they feel in the place, especially dwelling with others. Their habitats conditioned to the time determined by the institutions of control that regulate both space and time, do not prevent them from pointing out the benefits and advantages they find in the singular place appropriated by them and for them. In the park, they achieve self-affirmation through the intersubjective relationships they establish with the other young people, based on the strength of being together and sharing not only their experiences, in Benjamin's way, not as mere experiences (Erlebnis), if not as the practice of a deep experience (Erfahrung), given to an effort to realize their ideals (Benjamin, 1995).

The meanings of inhabiting the park are enunciated from enjoyment but are crossed by the possibility of being, that young being who seeks escape, escape from social pressures and impositions, just assuming the park as a vanishing point, momentary, fleeting, to his everyday life, their routines, their personal, family and economic conflicts.

Ideals of shared freedom, aesthetic enjoyment, socialization, common-union, 
community are the expressions of the young people from which they give meaning to their dwelling:

... Because I do not know, the environment, the environment goes with me I like to be in a free space where nobody says anything, where you can do what you can do and nobody judges you for who you are and much less (Angie, 2014).

"To do" without "no one to judge" is limited to the expressions of love they make among the members of the LGTBI community, therefore, "nobody" alludes to the community itself and the other young people, who observe affective practices without judging. For young people in the LGTBI community, other people, even those who limit and condition their presence in the park, are not an impediment to feeling free in loving exchanges. This sense of freedom emerges from the comparison between this type of expressions in the park and in other scenarios of the city from where they have been removed or where it is not allowed by the regulation and social controls that the spaces themselves impose.

[The park is] ... A place to meetand carrydifferent pointsof view, not only in the area below but also in the area above, we have the support of some of the rockers, as we call them here. And they defend us from the people who want to get us out, they are super cool people, most of them are only trying to meet different types of people (Diana, 2014).

From a physical-physiological perspective, the park, its organic architecture, open space with multiple entrances, circular shapes facilitates the connection between body-nature. The contact with the sun, the wind, the plants, arranges the bodies to rest, to the tranquility, in contrast with the dizzying pace and the bustle of the city. The noise does not reach there, neither the vehicular traffic, nor the smell of smoke that the cars expel, from the hill-hill where the park is located, the city is observed, the one in which they live but that from their place of room, they contemplate it. The symbolics of the park open the senses of the young and connect in an experience where seeing, hearing, smelling have more relevance.

The meaning associated with psychological experience comes from the search for themselves, the affirmation of their selves. If youth is assumed as a stage of the biological development of the human being in which he defines his sexual preferences as well as what will be of future life (especially for those who have options), the park ends up favoring the relations between similar ones with which can talk, talk about issues that affect them and, according to their experience, generate family and social rejection. Being gay, lesbian, belonging to a group, youth culture, "is not well seen" by the family or by the society of city, the like do not question behaviors or behavior and emotions, on the contrary, support and, by the way of conversational therapy, share their experiences of which they "learn" to cope with and overcome the inconveniences and circumstances presented to them.

As a social experience, the park is a party place and the people live it with intensity. The division of classes does not exist because all belong to the class of "marginalized", "excluded" and "rejected"; all of them have access similar to 
material and symbolic goods, reside in popular neighborhoods far from the park (except for one), all have economic restrictions, almost none of them have a job, some are in social moratorium, others are in search of employment and job opportunities, they all like to be with their friends therefore, the park is a common scenario for the socialization of young people.

The freedom expressed by young people as the meaning of the park for them, is interpreted as the place that favors affirmation of self in being with others, with others while they are being and building their "we".

It has always been like a meeting point with the people I like to be with, a place where oneself can do things without having to pay some money and without disturbing anyone, because it is a park place where one can just be quietly (Fulano, 2014).

In their habitation, the young experience the topophilia with the park, being the topophilia a poetic category of the spirit from which the perception of the place is mediated by the sensible experience and by the imaginative load what differentiates from the physical space, normal that does not is a lived or experienced space. Yi Fu-Tuan in 1974, quoted by Yory (2007), elaborates his definition of topophilia and relates it to a feeling of attachment, which is to an emotional-affective relationship that connects people with the places they feel identified with. That feeling exalts the symbolic level of human habitation and through it, it expresses belonging to the world and appropriation, so that topophilia is a feeling that has nothing to do with the geographer, you should look for it in the subject or in the modes in which the human being or a group of people, relate to the place through attributes.

Facing the process of growth and expansion of cities, there have been opposing situations, the loss of the sense of belonging and the desire of the inhabitants to identify with something, to feel that there is something inside the cities that belongs to them and therefore allows them to recognize themselves, this would be a premise in the communication-city relationship, people, who in this case are the young, have the right to places for coexistence, to project memory in urban places, to make the city a livable place, habitable; The place of room.

\subsection{Result 2: Communication}

The languages used by young people in their interactions are multiple. Verbal language, including silences, their own musical compositions, written text, their corporalities, movements and the images they produce with their bodies, their clothing, but also those images with which their skins are tattooed; Sounds, music: all forms of expression, creation and communication.

With their languages becoming visible, and just becoming visible, following Honneth (2011), means something more than knowing because, one thing is the visibility that alludes to the cognitive act of knowing and another is social visibility, which is a form of recognition. Knowledge refers to identification while recognition is knowledge with appreciation (Honneth, 2011: p. 170). This appreciation is what young people in the park are looking for when they come to 
different forms of expression and different languages to become visible. Language is the universal medium that allows understanding; all human talk is a display of meaning where speaking, as oral language and verbal expression, is only a language and an expressive form. Young people, turn to other languages to express themselves, including their bodies that are constituted in the center of aesthetics and territory of resistance, paint it, color it, mark it to make it seen. Corporalities, sonorities, kinesis and proxemics are the expressive ways in which young people construct their language.

It is the language of affections, which has a grammar, syntax and a semantics with which young people express themselves. This language has like nouns the kisses, the hugs, the gestures of contact, like the crosses of look, the laughter and with them they elaborate their grammars of the love but, likewise, they are present grammars of the pain, that they try to stop, well Either momentarily or while they live in the park.

The language of affections places affectivity as a central element in intersubjective relationships, being the affections of joy and sadness, those that enhance the action or the suffering of the young, in this way, appear grammars of love and pain that are registered in their bodies with nouns like kisses, hugs, smiles, tears but also the cry and aggressions with which they defend the place. With the grammars they express themselves and through the syntax they weave their us differing from the others, adults, neighbors, artisans and merchants; Also of the tourists. Youth cultures, arranged in affective communities, are tacitly or explicitly linked to each other, epithets of the young us, with which they are named and presented to others, and with the manifestation of their differentiated affections, the semantics of the recognition and contempt through which the acceptance between them is interpreted and the repudiation of a society-the otherstowards the difference, towards the different that is not different from the disenchantment that the young people by the world by which they create and recreate their own worlds.

In the language of affection there are several nouns like kiss, which is the expression of joy and happiness, is given and received in the face, in the head, in the arm and in the mouth. There are them as expressions of love, love, passion, also of comfort and compassion. Another noun is the handshake, with the clash of five fingers closed as a greeting, is the "I am with you". Holding hands is a noun of friendship, of love, of fraternity, more women do than men, they do it in their greeting ritual, and between women and men. The hug, strong, large such as if the time of the embrace was an indicator proportional to the affection of joy. Between them there are several ways to embrace and in the embrace, the gesture and the gaze intervene, when you see, from afar, the opening of the arms begins, it is as if they embrace with the heart, with the soul while little by little and slow steps, bodies come together. Physical contact is a necessity among young people, there the noun becomes action, the verb is embrace and the adverb is embraced, some young people remain embraced and they exchange the person they embrace, the important thing is to feel with the arms, to feel dear. 
The look is another noun that admits adjectives: flirty look, inquisitive look, airy look, questioning look, complicit look... many looks and multiple ways of looking at each other.

The semantics of the language of affections is the way to signify their collective youth actions that are far from the concept linked to social movements but are a form of political action for the defense of that place, its territory, which they inhabit to be. Here the semantics of the language of the affections is connected with the artivism (Delgado, 2013: p. 69) that defines for being the modes of struggle in the urban area. The social visibility that the young people demand, they do through the performances, to tattoo their skin, to paint their hair, to represent heroes and antiheroes as they do cosplay, bearers of swords and elements that simulate human supremacy as wanting power which is denied them and who seek through costumed costumes with those who escape their realities.

\subsection{Result 3: Recognition}

The reproduction of social life is accomplished under the imperative of reciprocal recognition, since subjects can only access a practical authorization if they learn to conceive themselves from the normative perspective of their interaction partners, as social recipients (Honneth, 1997). Therefore, from interactions among young people and following the patterns of intersubjective recognition it can be said that love is a form of recognition present in the intersubjective relationships of young people. The social integration between them, their emotional dedication present in reciprocal relationships of love or friendship is constituted in a form of recognition that is linked to the physical existence of people who profess feelings of special interest or love. Honneth (1997) argues that in order to speak of love, not only in the limited sense that the concept has taken from the romantic valorization of sexual intercourse, a neutral mode of employment is advisable: by loving relationships all primary relationships must be understood here, to the extent that, as in the case of erotic relations between them, friendships or parent-child relationships are in strong affective bonds, therefore love relationships are not limited to those relationships mediated by the love of a partner or by the eroticism but to the basic relationships of filial and fraternal love that in the case of young people, the feelings of love and friendship find it and express it in and with their peers.

This is what happens in the collective experience of inhabiting the park by the youth and only among them, that is to say, within their group, youth culture or among the youth of the LGTBI community. Hugs, kisses, the need to be together, piled up, cornered and proxemics with their intimate and personal distance in the near phase realize this form of recognition with their affective character of acceptance and encouragement which gives them self-confidence.

I find it excellent, beautiful, harmonious because we are part of different cultures, but if we are united by something and that is the quality of being differtent, we are basically free, I am what I am because I live with unconformity with what surrounds me and that is something that more than one thinks here, for 
me it is like my family, there are many that I do not know but for the simple fact of being here they are like my family and they deserve respect... we start to shout music, to learn songs and another the follow and see that we communicate and we have something in common and that has left us some message (Fulano, 2014).

The other form of recognition present in the relations between young people corresponds to solidarity as a community of value. In the conditions of modern society, solidarity is linked to the budget of social relations of symmetrical valuation between individualized and autonomous subjects; in this sense, to value one symmetrically means to consider each other in the light of the values that make appear the capacities and qualities of any other as significant of the common praxis.

There is, among youth groups and cultures, a relationship of solidarity and an appreciation for individually developed forms of life (Honneth, 2010: p. 28), which emphasize respect for difference, the valuation of different cultural practices carried out by diverse young people and there is solidarity to support the cause of a group that at times acquires nuances of complicity. Some groups formed by young people in the park accompany the social and political causes of others, as it happens with the collective Botas Negras that has accompanied the marches of the LGTBI community in which they fight for their rights, such as the March for Gay Pride.

The park is a place to know and have different types of sight, not only in the area below but also in the area above. We have the support of some of the rockers, as we call them here, they defend us from the people who want to take us out, they are super people (Diana, 2014).

When it comes to analyzing the relationship between young people and the adult world, forms of contempt appear. Abuse or physical harm becomes a moral injustice if the affected person sees in him an act that intentionally belittles him in an essential aspect of his well-being. The first form of contempt is found in these experiences of bodily mistreatment that destroy the elemental self-confidence of the person (Honneth, 1997). This form of contempt is characterized by the manifestations of repudiation, verbal aggressions and indications by the gender and the sexual option of some young people. Homophobia, lesbophobia are feelings of rejection on the part of the adults, exerted by some artisans, neighbors and policemen.

The dispossession of rights means being injured in their expectations of being recognized as a subject capable of forming moral judgments, therefore, the dispossession of rights is linked to a loss of self-respect, hence the ability to refer to itself as a subject of legitimate and equal interaction with others (Honneth, 1997).

... if you come to relax in a park and all day have been watched or are stopped or stopped from somewhere... sometimes they pass [the police] there are respectful but few. I say that the human is born well and society corrupts it, after they have a uniform and are giving authority, after they give a stick abuse and 
forget that they are from the people too and abuse people. I've seen a lot of repression until 1 ve been a victim of it (Fulano, 2014).

The third form of contempt corresponds to the indignity, the dishonor, that in the tensions of the young with the adult world are evident in the constant calls and calls to the authority for the preservation of the "order" are reflected in the valuations that the young people feel to be investigated in their relationship with adults. The evaluative degradation of a certain model of self-realization, results in not being able to refer to their way of living as something that, within the community, is attributed to a positive meaning; thus, for the individual with the experience of such devaluation, there is a loss of personal self-esteem and, consequently, of the opportunity to be understood as an entity estimated in its capacities and qualities (Honneth, 1997).

\section{Conclusions}

The verbal, nonverbal, visual languages are amalgamated in the young and produce other visuality, corporalities, sonorities in the dwelling with which they construct their language: the language of affections that places affectivity as a central element in intersubjective relationships. With the language of affections they become visible; they attract attention because they accentuate the expression of their affections and emotions. Youth cultures, arranged in affective communities, are linked to each other, tacitly or explicitly and outside the adults. Their communication is related to harmonious coexistence but only between them because they are aware of the rejection they cause among some adults. Before the disenchantment that the young people have by the world, they create and recreate their own worlds in their dwelling.

In the being together of the young inhabit the place do not occupy it; in this differentiation emerges the relationship topophilia that established with the place itself. The tensions that arise with the commercial park, the artisans and with the social park, the neighbors, together with police surveillance, constitute motivations for the struggle and thus claim the right to the city, city for to live and to be. Given the impending co-optation of the city by the market, the alternative of young people is to fight for the public spaces where they can be; It is a question of claiming the rebellious cities of Harvey (2013) and the city is a place to live and not a place to invest, which excludes low-income people, including young people, from accessing the city because of their City merchandise, because they affect the neoliberal landscape.

Collective actions, a concept that historically has been linked to social movements conceived, according to Delgado based on Melucci, "as agencies of collective significance that spread new meanings in society through collective action (Delgado, 2009: p. 37). The groupings and localized groupings of these young people are closer to the movements or repertoires of mobilization (Aguilera, 2012) but with their collective actions understood as a social phenomenon that alludes to the process of coordination of actions between individuals that arise from a social and they participate in the social scene through artivism, hybrid 
actions, a mixture of collective action and art through which young people express themselves and show their discontent and disgust in society. Artivism is expressed in the seedlings, the chants, the kisses, and the open expression of their sexual orientation, which they call freedom.

Society is not homogeneous, much less uniform but still people, traditional institutions insist on maintaining hegemony, asymmetric relations of power obscuring and making invisible diversity. What happens in the public sphere is clearly seen in a social scenario such as the park, where the disgust and repugnance is reproduced in relation to what is left of conventional, traditional norms. Intersubjective recognition among young people is manifested in the relationships of love and solidarity that unfold and are perceptible in being together; however, the other actors who occupy the park do not agree with the presence of young people because they consider that they affect their Economic interests and prevent the sociability of children and families who visit the place. Therefore, more than recognition, what is evidenced are the forms of contempt of young people, especially those belonging to the LGBTI community, given the appellations, which adults use to name them, in the semantic load of adjectives with which point to them due to tensions over the belief system/dogmas of some adults and to the way citizenship is rooted in traditions and resists the acceptance of the other, the other, the others.

\section{References}

Aguilera, O. (2012). Repertorios y ciclos de movilización juvenil en Chile (2000-2012). Utopía y Praxis Latinoamericana. Año 17, No. 57, 101-108.

Alcaldía de Santiago de Cali (2012). Visión Cali, Boletín informativo No. 12. Recuperado el 10 de 2014 de enero, de Observatorio social: http://www.cali.gov.co/observatorios/publicaciones/informes_diario_mensual_pub

Alcaldía de Santiago de Cali (2013). Cali en cifras . Cali: Imprenta departamental.

Angie (23 de junio de 2014). Conversación con joven. (M. M. Cataño, Entrevistador).

Benjamin, W. (1995). La metafísica de la juventud. Barcelona: Altaya.

Curran, J., Morley, D., \& Walkerdine, V. (1998). Estudios culturales y comunicación. Barcelona: Paidos.

Delgado, M. (2013). Artivismo y pospolítica. Sobre la estetización de las luchas sociaes en contextos urbanos. Recuperado el 15 de junio de 2016, de Instituto Catalá d'Antropologia: www.antropologia.cat

Delgado, R. (2009). Acción colectiva y sujetos sociales. Bogotá: Editorial PUJ.

Diana. (2014). Conversación con joven. (M. M. Cataño O., Entrevistador)

Fulano. (2014). Conversación con joven. (M. M. Cataño O., Entrevistador)

Harvey, D. (2013). Ciudades rebeldes. Del derecho a la ciudad a la revolución urbana. Madrid: Akal.

Honneth, A. (1997). La lucha por el reconocimiento. Por una gramática moral de los conflictos sociales. Barcelona: Katz.

Honneth, A. (2010). Reconocimiento y menosprecio. Sobre la fundamentación normativa de una teoría social. Barcelona: Katz Editores.

Honneth, A. (2011). La sociedad del desprecio. Madrid: Trotta. 
Lara, A., \& Domínguez, G. (2013). El giro afectivo. The Affective Turn. Athenea Digital, 101-119.

Moran, D. (2011). Introducción a la Fenomenología. Barcelona: Anthropos.

Sarto, A. D. (2012). Los afectos en los estudios culturales. Cuerpos y subjetividades en Ciudad Juarez. Cuadernos de literatura, No. 32, 41-68.

Spinoza, B. (1980). Ética demostrada según el orden geométrico. Barcelona: Orbis.

Yory, C. (2007). Topofilia o la dimensión poética del habitar. Bogotá: PUJ.

Submit or recommend next manuscript to SCIRP and we will provide best service for you:

Accepting pre-submission inquiries through Email, Facebook, LinkedIn, Twitter, etc. A wide selection of journals (inclusive of 9 subjects, more than 200 journals)

Providing 24-hour high-quality service

User-friendly online submission system

Fair and swift peer-review system

Efficient typesetting and proofreading procedure

Display of the result of downloads and visits, as well as the number of cited articles

Maximum dissemination of your research work

Submit your manuscript at: http://papersubmission.scirp.org/

Or contact ajc@scirp.org 